\title{
Effects of level and form of dietary zinc on dairy cow performance and health
}

\author{
C. M. Cope, ${ }^{*}$ A. M. Mackenzie, ${ }^{*}$ D. Wilde, $\dagger$ and L. A. Sinclair ${ }^{* 1}$ \\ ${ }^{*}$ Animal Science Research Centre, Harper Adams University College, Newport, Shropshire, TF10 8NB, United Kingdom \\ †Alltech (UK) Limited, Alltech House, Ryhall Road, Stamford, Lincolnshire, PE9 1TZ, United Kingdom
}

\section{ABSTRACT}

A basal mixed ration supplying $36 \mathrm{mg}$ of $\mathrm{Zn} / \mathrm{kg}$ of dry matter (DM) was supplemented with 1 of 4 concentrates differing in level and form of dietary Zn. The concentrates were fed at $2 \mathrm{~kg} / \mathrm{cow}$ per day and contained $300 \mathrm{mg}$ of $\mathrm{Zn} / \mathrm{kg}$ (to supply the total recommended level, according to NRC (2001); R) or 60 $\mathrm{mg}$ of $\mathrm{Zn} / \mathrm{kg}$ (to supply 0.66 of the total recommended level; L), either supplemented as $\mathrm{ZnO}$ (I) or organically chelated Zn (O). Forty-four Holstein-Friesian dairy cows (12 primiparous and 32 multiparous), on average $31 \mathrm{~d}(\mathrm{SD} \pm 11.4)$ into lactation, were allocated to 1 of the 4 treatments. All cows remained on the treatment for $14 \mathrm{wk}$. The data was analyzed by ANOVA as a $2 \times 2$ factorial design. Dry matter intake averaged $23.5 \mathrm{~kg} / \mathrm{d}$ and did not differ between treatments. Cows supplemented with organically chelated $\mathrm{Zn}$ at the recommended level of inclusion (RO) had a higher milk yield $(37.6 \mathrm{~kg} / \mathrm{d})$ than those fed inorganic $\mathrm{Zn}$ at the recommended level (RI; $35.2 \mathrm{~kg} / \mathrm{d}$ ) or organically chelated $\mathrm{Zn}$ at the low level (LO; $35.2 \mathrm{~kg} / \mathrm{d}$ ), but was not different from those fed inorganic $\mathrm{Zn}$ at the low level (LI; $36.0 \mathrm{~kg} / \mathrm{d}$ ). Milk composition was unaffected by dietary treatment. Animals that received the low level of $\mathrm{Zn}$ (LI and LO) had higher somatic cell counts [3.97 and 3.93 versus 4.35 and $4.55\left(\log _{\mathrm{e}}\right)$ for RI, RO, LI, and LO, respectively] and milk amyloid A levels than those receiving the recommended levels (RO and RI). There was no effect of treatment on body condition score, body weight, or locomotion score. Hoof hardness improved over the duration of the study but there were no differences between treatments. Similarly, blood plasma mineral levels for $\mathrm{Zn}, \mathrm{Cu}, \mathrm{Mo}$, and $\mathrm{Fe}$ were not affected by treatment, whereas there was a trend for increased ceruloplasmin levels in cows receiving the recommended compared with the low level of Zn, but there was no effect of mineral form. There was also no effect of treatment on superoxide dismutase activity or blood hematology. It is concluded that supplementing $\mathrm{Zn}$ at the recommended level reduced somatic cell counts and

Received April 4, 2008.

Accepted December 3, 2008.

${ }^{1}$ Corresponding author: lsinclair@harper-adams.ac.uk milk amyloid A levels, whereas supplementation in an organic form at the recommended level also increased milk yield.

Key words: dairy cow, zinc, milk production, somatic cell count

\section{INTRODUCTION}

The micronutrient $\mathrm{Zn}$ has been established as an essential component of the dairy cow's diet for maintaining health and performance. Traditionally, cattle diets have been supplemented with inorganic minerals (e.g., $\mathrm{ZnO}$ ), but it has been suggested that the quantity of mineral ingested by the animal may not be as important as the form (Spears, 1996).

The involvement of $\mathrm{Zn}$ in maintaining the status of the immune system has been documented and it has been suggested that a deficiency could result in increased SCC and ultimately mastitis rates (Whitaker et al., 1997). The inclusion of organically chelated Zn has been reported to reduce SCC of high-producing dairy cows, particularly when the initial SCC was high. For example, herds with SCC averaging more than 400,000 cells/mL had a decrease of approximately 100,000 cells/ $\mathrm{mL}$ when supplemented with $2.5 \mathrm{~g} / \mathrm{d}$ of Zn proteinate (Hansen, 1992). By contrast, other studies that have been conducted in animals with low SCC $(150,000$ cells $/ \mathrm{mL}$ ) at the start of the experiment reported that organically chelated Zn had no effect on SCC, but resulted in a decrease in mastitis rates (Spain et al., 1993). Similarly, Whittaker et al. (1997) examined the effects of zinc methionine against $\mathrm{ZnO}$ on SCC and found no significant effect.

A greater concentration of $\mathrm{Zn}$ is present in the harder keratin of the hoof wall compared with the softer keratin in the heel (Baggott et al., 1988). The interruption of nutrient supply to the keratin-forming cells could result in the formation of inferior keratin tissue, potentially causing claw disorders and subsequent lameness (Tomlinson et al., 2004). If the bioavailability of trace minerals is increased, this could lead to improved production in the keratinized tissues of the claw, ultimately reducing lameness incidence (Tomlinson et al., 2004).

The objectives of this study were to examine the effects of an organic source of dietary Zn as a replacement 
for inorganic Zn on performance, milk Zn concentration, udder health, locomotion, and hoof hardness when fed at the level recommended by the NRC (2001) for early lactating cows or below the recommended level [0.66 of NRC (2001)].

\section{MATERIALS AND METHODS}

The work described in this paper was conducted in accordance with the UK Animals (Scientific Procedures) Act 1986.

\section{Animals}

Forty-four Holstein-Friesian dairy cows (12 primiparous and 32 multiparous) were used in a 14-wk continuous design study. Animals commenced the study $31 \mathrm{~d}$ (SD \pm 11.4 ) into lactation and were blocked based on parity (primiparous or multiparous), milk yield [mean 35.8 (SD 6.95) $\mathrm{kg}$ ], milk fat [mean 1.56 $(\mathrm{SD} 0.53) \mathrm{kg} / \mathrm{d}$ ], milk protein [mean 1.17 (SD 0.21) $\mathrm{kg} / \mathrm{d}$ ] and BCS [Lowman et al., 1976; mean 2.5 (SD $0.52)]$ and randomly allocated to 1 of 4 treatments. The animals were housed in the same cubicle shed containing Pasture Mats (Promat Inc., Ontario, Canada) with all cows having continual access to water. The cubicle passageways were scraped using automatic scrapers set to run every $3 \mathrm{~h}$; cubicles were bedded twice weekly with chopped paper and limed weekly.

\section{Diet and Concentrate Preparation}

All cows received the same basal diet, which was predicted to supply $36 \mathrm{mg} / \mathrm{kg} \mathrm{DM}$ of $\mathrm{Zn}$ per cow per day (Table 1). The corn and grass silages were fed in the ratio of 2:1 (DM basis), with the ratio being maintained by oven-drying forage samples taken twice weekly. The minerals added to the total mixed ration (Rumenco, Staffordshire, UK) contained no Zn and contained (per $\mathrm{kg}$, DM basis), $160 \mathrm{~g}$ of calcium, $80 \mathrm{~g}$ of phosphorus, $70 \mathrm{~g}$ of sodium, $10 \mathrm{~g}$ of magnesium, $45 \mathrm{mg}$ of sodium selenite, $50 \mathrm{mg}$ of cobalt carbonate, $250 \mathrm{mg}$ of calcium iodate, $1,000 \mathrm{mg}$ of manganous oxide, $2,500 \mathrm{mg}$ of cupric sulfate, and 2,250, 90,000 and 450,000 IU/kg of vitamins $\mathrm{E}, \mathrm{D}_{3}$, and $\mathrm{A}$ respectively. The concentrates (M. E. Waterhouse, Malpas, UK) contained $(\mathrm{g} / \mathrm{kg}$, fresh weight) wheat 249 , soybean meal 200 , palm kernel 180, sugar beet pulp (molassed) 150, soybean hulls 100, molasses 70, Megalac (Volac UK Ltd., Royston, UK) 25, 16 of a mineral mix containing either $\mathrm{ZnO}$ (Rumenco, Staffordshire, UK) or Bioplex Zn (Alltech Inc., Nicholasville, KY), and limestone 10. The concentrates were formulated to contain $300 \mathrm{mg}$ of $\mathrm{Zn} / \mathrm{kg}$ [to supply the total recommended level, according to
Table 1. Ingredient composition of the basal diet

\begin{tabular}{|c|c|}
\hline Ingredient & Amount $(\mathrm{kg} / \mathrm{kg}$ of $\mathrm{DM})$ \\
\hline Corn silage & 0.39 \\
\hline Grass silage & 0.19 \\
\hline Urea-treated wheat & 0.08 \\
\hline Sugar beet feed ${ }^{1}$ & 0.07 \\
\hline Soybean meal & 0.08 \\
\hline Rapeseed meal & 0.08 \\
\hline Maize gluten & 0.03 \\
\hline Molasses & 0.05 \\
\hline Megalac $^{2}$ & 0.02 \\
\hline Minerals & 0.01 \\
\hline \multicolumn{2}{|l|}{ Calculated composition ${ }^{3}$} \\
\hline OM (g/kg of DM) & 932 \\
\hline $\mathrm{CP}(\mathrm{g} / \mathrm{kg}$ of $\mathrm{DM})$ & 168 \\
\hline $\mathrm{NDF}(\mathrm{g} / \mathrm{kg}$ of $\mathrm{DM})$ & 320 \\
\hline Starch $(\mathrm{g} / \mathrm{kg}$ of $\mathrm{DM})$ & 144 \\
\hline $\mathrm{ME}(\mathrm{MJ} / \mathrm{kg}$ of $\mathrm{DM})$ & 11.8 \\
\hline Zn (mg/kg DM) & 36 \\
\hline
\end{tabular}

${ }^{1}$ By-product of the manufacture of sugar, consisting of extracted sugar beet slices and sugar beet molasses, which have been dried (Trident Feeds, Peterborough, UK).

${ }^{2}$ Calcium soap of palm oil fatty acids (Volac Ltd., Royston, Hertfordshire, UK).

${ }^{3}$ Calculated from analyzed values for grass and corn silage; standard values (NRC, 2001) for other ingredients.

NRC (2001); R] or $60 \mathrm{mg}$ of $\mathrm{Zn} / \mathrm{kg}$ (to supply 0.66 of the total recommended level; $\mathbf{L}$ ), either supplemented as $\mathrm{ZnO}(\mathbf{I})$ or organically chelated $\mathrm{Zn}$ (Bioplex $\mathrm{Zn} ; \mathbf{O}$ ). The lower level was equivalent to $20 \%$ of the amount supplemented in the $\mathrm{R}$ concentrate. Bioplex Zn proteinate is formed by reacting $\mathrm{Zn}$ with a prepared mixture of amino acids and small peptides under controlled conditions, and contained $10 \% \mathrm{Zn}$. All 4 concentrates were fed at the rate of $2 \mathrm{~kg} / \mathrm{cow}$ per d through out-of-parlor feeders.

\section{Experimental Procedure}

Animals received the basal mix through feed bins (Insentec, Marknesse, the Netherlands), which allowed measurement of individual feed intake by means of weigh cells located in the bins and transponders on collars worn by the cows. The cows received the basal ration once daily at $0900 \mathrm{~h}$ at the rate of $105 \%$ of the previous calculated daily intake with refusals removed twice weekly. Cows were milked twice daily at approximately $0500 \mathrm{~h}$ and $1600 \mathrm{~h}$. Milk yield was recorded automatically at each milking and samples were taken for the determination of milk composition weekly at 2 consecutive milkings, with additional samples taken fortnightly for SCC and milk amyloid A. Samples for SCC determination were analyzed within $24 \mathrm{~h}$ (Direct Laboratories, Wolverhampton, UK), while samples from the morning milking were stored at $-20^{\circ} \mathrm{C}$ before milk amyloid A analysis. Each week after the evening 
milking, animals were weighed using a weigh crate (TruTest Ltd., Auckland, New Zealand); BCS was scored based on a 5 -point scale with 0.25 intervals, where $1=$ thin and $5=$ fat; and locomotion was scored (Manson and Leaver, 1988) on a 5-point scale, where $1=$ normal and $5=$ severely lame. The same technician scored the cows each week.

During wk 0, 4, 8, 12, and 14 of the study, blood samples were taken via venipuncture from the jugular vein at $1000 \mathrm{~h}$. Samples were collected into vacutainers (Becton Dickinson Vacutainer Systems, Plymouth, UK) containing either EDTA (for samples used to determine whole blood hematology), silica (for samples used to determine ceruloplasmin), or lithium heparin (for samples used to determine superoxide dismutase activity), and after centrifuging at $1,000 \times g$ for $15 \mathrm{~min}$ at $4^{\circ} \mathrm{C}$, the plasma was removed and stored at $-20^{\circ} \mathrm{C}$ before determination of plasma trace elements. Silica tubes were refrigerated for $24 \mathrm{~h}$ before centrifuging and subsequent removal of serum, which was stored at $-20^{\circ} \mathrm{C}$ before ceruloplasmin analysis.

All cows were tested for hoof hardness using a Shore Scale D durometer (Bowers Metrology UK Limited, Hampshire, UK; Griffiths et al., 2007). The front right hooves were cleaned and measurements taken against the hoof wall at approximately $0.5 \mathrm{~cm}$ below the coronary band. Recordings were carried out at wk 0,7 , and 14, with 10 measurements taken from the front to the heel of the hoof, and the mean value recorded for each time point.

\section{Chemical Analysis}

Feed samples were collected twice weekly and bulked every $5 \mathrm{wk}$, with a representative subsample sent to Natural Resource Management Laboratories Ltd., Berkshire, UK, for analysis (Table 2) as described by Jackson et al. (2004). All feed samples were analyzed for $\mathrm{Zn}$ content using the DigiPREP digestion system (Qmx Laboratories, Essex, UK). A total of $0.5 \mathrm{~g}$ of oven-dried, milled sample was accurately weighted into a DigiTUBE and $1 \mathrm{~mL}$ of $\mathrm{HCl}$ and $6 \mathrm{~mL}$ of $\mathrm{HNO}_{3}$ added. The tubes were then placed into the DigiPREP and heated to $45^{\circ} \mathrm{C}$ and held for 1 min before being increased up to $65^{\circ} \mathrm{C}$ and held for another $5 \mathrm{~min}$. The temperature of the sample was then increased to $100^{\circ} \mathrm{C}$ and refluxed for $40 \mathrm{~min}$ for the forages and $45 \mathrm{~min}$ for the concentrates. The samples were then diluted with distilled water before analysis by inductively coupled plasma-mass spectrometry (Thermo Fisher Scientific Inc., Hemel Hempstead, UK). Milk samples were analyzed for fat, protein, and lactose content using a FTIR Lactoscope (Delta Instruments, Drachten, the Netherlands) and analyzed for milk amyloid A using a phase
Table 2. Chemical composition of the concentrates fed through outof-parlor feeders ${ }^{1}$

\begin{tabular}{lcccc}
\hline Item & $\mathrm{RI}^{2}$ & $\mathrm{RO}$ & $\mathrm{LI}$ & $\mathrm{LO}$ \\
\hline $\mathrm{DM}, \mathrm{g} / \mathrm{kg}$ & 878 & 881 & 884 & 878 \\
ME, MJ/kg of DM & 13.0 & 12.9 & 12.9 & 12.8 \\
NDF, g/kg of DM & 334 & 338 & 338 & 328 \\
Ash, g/kg of DM & 77 & 77 & 77 & 78 \\
Oil, g/kg of DM & 6 & 6 & 6 & 6 \\
CP, g/kg of DM & 216 & 208 & 207 & 206 \\
Starch, g/kg of DM & 177 & 173 & 179 & 186 \\
Sugar, g/kg of DM & 85 & 87 & 88 & 87 \\
Zn, mg/kg of DM & 343 & 370 & 106 & 103 \\
\hline
\end{tabular}

${ }^{1}$ All concentrates were fed at the rate of $2 \mathrm{~kg} /$ cow per day.

${ }^{2}$ Concentrates were predicted to supply: $\mathrm{RI}=$ recommended daily level of inorganic $\mathrm{Zn}$; RO = recommended level of organic $\mathrm{Zn}$; LI = low (0.66 of the recommended) level of inorganic $\mathrm{Zn} ; \mathrm{LO}=$ low level of organic Zn.

serum amyloid A assay kit (Tridelta Development Ltd., Maynooth, Ireland; Eckersall et al., 2001). Milk Zn was analyzed by diluting milk samples 1:20 in a solution of $0.05 \%$ tetramethylammonium hydroxide (TMAH; 99.9\% purity, Fisher Scientific, Leicestershire, UK), $0.01 \%$ Triton-X (Fisher Scientific, Leicestershire, UK) and $0.5 \%$ butanol (VWR, Leicestershire, UK). Whole blood samples were analyzed for white blood cells, red blood cells, hemoglobin, hematocrit, platelets, mean corpuscular volume, mean corpuscular hemoglobin, and mean corpuscular hemoglobin concentration using a Vet Animal Blood Counter (Woodley Equipment Company Ltd., Bolton, UK) and superoxide dismutase (Ransod, Kit catalog no. SD 125; Randox Laboratories, Crumlin, UK) using a Cobas Miras Plus autoanalyser (ABX Diagnostics, Bedfordshire, UK). Plasma samples were analyzed for $\mathrm{Zn}, \mathrm{Cu}, \mathrm{Fe}$, and Mo by inductively coupled plasma-mass spectrometry by diluting 1:20 in $0.5 \% \mathrm{HNO}_{3}$ and serum samples analyzed for ceruloplasmin based on the method of Henry et al. (1974), using a Cobas Miras Plus auto-analyzer (ABX Diagnostics).

\section{Statistical Analysis}

The data were analyzed by ANOVA as a $2 \times 2$ factorial design with milk production or BW in the $7 \mathrm{~d}$ before allocation being used, where appropriate, as a covariate. Treatment degrees of freedom were split into main effects of $\mathrm{Zn}$ level (R vs. L), form of Zn (I vs. $\mathrm{O})$, and their interaction $(\mathrm{L} \times \mathrm{F})$ and was analyzed according to

$$
\mathrm{y}_{\mathrm{i}}=\mu+\mathrm{B}_{\mathrm{i}}+\mathrm{l}_{\mathrm{j}}+\mathrm{f}_{\mathrm{k}}+\mathrm{l} \times \mathrm{f}_{\mathrm{jk}}+\varepsilon_{\mathrm{ijkl}}
$$

where $\mathrm{y}_{\mathrm{i}}=$ dependent variable; $\mu=$ overall mean; $\mathrm{B}_{\mathrm{i}}=$ random effect of blocks; $l_{j}=$ effect of level $(j=$ recommended level, low level); $\mathrm{f}_{\mathrm{k}}=$ effect of form of $\mathrm{Zn}(\mathrm{k}=$ 
Table 3. Effect of level and form of dietary Zn on dairy cow performance and health

\begin{tabular}{|c|c|c|c|c|c|c|c|c|}
\hline Item & \multicolumn{4}{|c|}{ Treatments } & SEM & \multicolumn{3}{|c|}{ Significance } \\
\hline Total diet $\mathrm{Zn}, \mathrm{mg} / \mathrm{kg}$ of $\mathrm{DM}$ & 62.7 & 63.9 & 41.8 & 41.4 & & & & \\
\hline Milk yield, $\mathrm{kg} / \mathrm{d}$ & $35.2^{\mathrm{a}}$ & $37.6^{\mathrm{b}}$ & $36.0^{\mathrm{ab}}$ & $35.2^{\mathrm{a}}$ & 0.96 & 0.268 & 0.247 & 0.026 \\
\hline Fat, $\mathrm{g} / \mathrm{kg}$ & 40.7 & 41.0 & 41.9 & 42.0 & 1.67 & 0.372 & 0.909 & 0.879 \\
\hline Fat yield, $\mathrm{kg} / \mathrm{d}$ & 1.44 & 1.50 & 1.49 & 1.50 & 0.053 & 0.312 & 0.525 & 0.557 \\
\hline $\mathrm{SCC}, \log _{\mathrm{e}}$ & $3.97^{\mathrm{a}}$ & $3.93^{\mathrm{a}}$ & $4.35^{\mathrm{b}}$ & $4.55^{\mathrm{b}}$ & 0.430 & 0.022 & 0.717 & 0.587 \\
\hline Milk amyloid $\mathrm{A}, \mu \mathrm{g} / \mathrm{mL}$ & $0.90^{\mathrm{a}}$ & $0.88^{\mathrm{a}}$ & $1.21^{\mathrm{b}}$ & $1.57^{\mathrm{b}}$ & 0.295 & 0.023 & 0.412 & 0.375 \\
\hline $\mathrm{BW}, \mathrm{kg}$ & 609 & 608 & 621 & 616 & 10.1 & 0.114 & 0.707 & 0.803 \\
\hline $\mathrm{BCS}^{3}$ & 2.49 & 2.33 & 2.48 & 2.53 & 0.090 & 0.205 & 0.459 & 0.164 \\
\hline Locomotion score $^{4}$ & 2.94 & 2.88 & 2.68 & 2.87 & 0.170 & 0.280 & 0.582 & 0.303 \\
\hline
\end{tabular}

${ }^{\mathrm{a}, \mathrm{b}}$ Within a row, means without a common superscript letter differ $(P<0.05)$.

${ }^{1}$ Diets contained: $\mathrm{RI}=$ recommended daily level of inorganic $\mathrm{Zn}$; RO = recommended level of organic $\mathrm{Zn}$; LI = low (0.66 of the recommended) level of inorganic $\mathrm{Zn}$; LO = low level of organic $\mathrm{Zn}$.

${ }^{2} \mathrm{~L}=$ main effect of level of $\mathrm{Zn} ; \mathrm{F}=$ main effect form of $\mathrm{Zn} ; \mathrm{L} \times \mathrm{F}=$ interaction between level and form of $\mathrm{Zn}$.

${ }^{3} \mathrm{BCS}$ based on a 5 -point scale (Lowman et al., 1976) with 0.25 intervals, where $1=$ thin and $5=$ fat.

${ }^{4}$ Locomotion scored (Manson and Leaver, 1988) based on a 5 -point scale, where $1=$ normal and $5=$ severely lame.

$+,-) ; 1 \times \mathrm{f}_{\mathrm{jk}}=$ interactions between the 2 variables; and $\varepsilon_{\mathrm{ijkl}}=$ residual error.

Blood hematology data, plasma biochemistry, and milk parameters were analyzed by repeated measures ANOVA. The model for these repeated measures included the effects of time, treatment, interaction between treatment and time, and the block of each animal. All statistical analysis was conducted using Genstat version 8.1 (VSN Int. Ltd., Oxford, UK) with means and standard error of the mean presented; $P<$ 0.05 was used as the significant threshold.

\section{RESULTS}

\section{Concentrate Analysis}

The DM content of the 4 concentrates was similar with an average of $880 \mathrm{~g} / \mathrm{kg}$, while RI had the highest $\mathrm{CP}$ content and LO the lowest (Table 2). All 4 concentrates had Zn concentrations similar to that predicted, with RI and RO having the highest levels (mean of 356 $\mathrm{mg} / \mathrm{kg}$ of DM) and LI and LO the lowest (mean of 104 $\mathrm{mg} / \mathrm{kg}$ of $\mathrm{DM}$ ).

\section{Intake, Animal Performance, and Blood Parameters}

Dry matter intake averaged $23.5 \mathrm{~kg} / \mathrm{d}$ and did not differ $(P>0.05)$ between treatments (Table 3$)$. There was an interaction effect of level and form of treatment on mean milk yield over the 14 -wk period, with cows receiving RO having a higher production $(P<0.05)$ than those fed RI or LO, but not those receiving LI.
In wk 8,9 , and 11 , there was an increase $(P<0.05)$ in milk yield for cows receiving $\mathrm{RO}$ compared with any of the treatments (Figure 1). There was no effect of time or time $\times$ treatment interaction $(P>0.05)$ on milk composition, with average fat and protein values of 41.4 and $33.1 \mathrm{~g} / \mathrm{kg}$, respectively. The concentration of $\mathrm{Zn}$ in milk also did not differ $(P>0.05)$ between the treatment groups, and there was no effect $(P>$ 0.05) of treatment on BW or BCS. In contrast, animals receiving the recommended level of $\mathrm{Zn}$ had reduced $(P$ $<0.05)$ SCC and milk amyloid A concentrations compared with those fed the low dietary level.

There was no effect $(P>0.05)$ of treatment on hoof hardness (Figure 2) at any of the time points. There was also no effect $(P>0.05)$ of treatment on mean locomotion score (Table 3). Similarly, blood plasma Zn, $\mathrm{Cu}, \mathrm{Mo}$, and $\mathrm{Fe}$ were not affected by time, treatment, or time $\times$ treatment interaction $(P>0.05$; Table 4$)$. A tendency for an increase $(P=0.05)$ in ceruloplasmin levels was found in cows receiving the recommended level of $\mathrm{Zn}$ compared with the low level, but there was no effect $(P>0.05)$ of mineral form. There was also no effect of time, treatment, or time $\times$ treatment interaction $(P>0.05)$ on superoxide dismutase, red blood cell related variables, or blood hematology.

\section{DISCUSSION}

It has been suggested that organic minerals have an increased bioavailability, resulting in an increased absorption in the gastrointestinal tract (Spears, 1996). This may lead to an improvement in performance or 


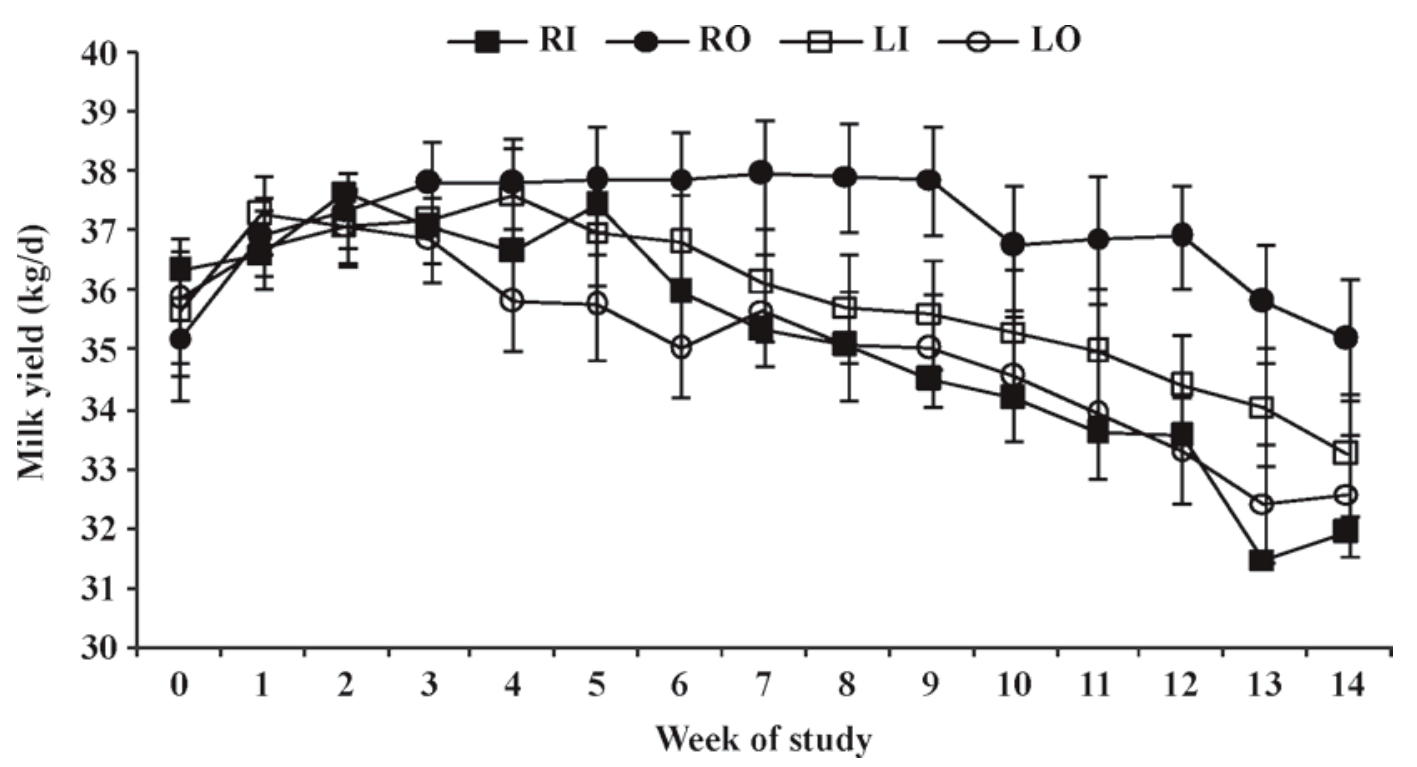

Figure 1. Effect of level and form of dietary $\mathrm{Zn}$ on daily milk yield $(\mathrm{kg} / \mathrm{d})$ of cows fed diets that contained either the recommended level of inorganic (RI) or organic (RO) Zn or 0.66 of the recommended level per d of inorganic (LI) or organic (LO) Zn (Week 0 corresponds to the start of the study). Error bars $=$ SEM.

health or may reduce the level of $\mathrm{Zn}$ supplement required in the diet, although reports in the literature on the effects of level and form of Zn are conflicting.

The level of $\mathrm{Zn}$ fed during this study ranged from 40 to $65 \mathrm{mg} / \mathrm{kg} \mathrm{DM}$ and had no effect on DM intake during the 14-wk study. Malcolm-Callis et al. (2000) reported a reduction in DM intake for steers when supplemented with increasing concentrations of $\mathrm{Zn}$ in the diet (20, 100 , and $200 \mathrm{mg}$ of $\mathrm{Zn} / \mathrm{kg}$ of $\mathrm{DM})$. It was reported that the reduction in DM intake may have been due to the higher level of $\mathrm{Zn}$ having a negative effect on palatability, and the levels fed during the current study were well below the maximum used by Malcolm-Callis et al. (2000). Malcolm-Callis et al. (2000) also looked at supplementing $\mathrm{Zn}$ in different forms and found no difference in DM intake when Zn was supplemented as $\mathrm{Zn}$ sulfate $\left(\mathrm{ZnSO}_{4}\right), \mathrm{Zn}$ amino acid complex, or a $\mathrm{Zn}$ polysaccharide complex over a 126-d period, a finding that agrees with the current results and suggests that the form of Zn has little effect on DM intake in cattle.

Nocek et al. (2006) reported no change in BW or BCS of dairy cows when Zn was supplemented at $75 \%$ or $100 \%$ of NRC (2001) requirements, but background Zn levels in the diet (which in the current study contrib-

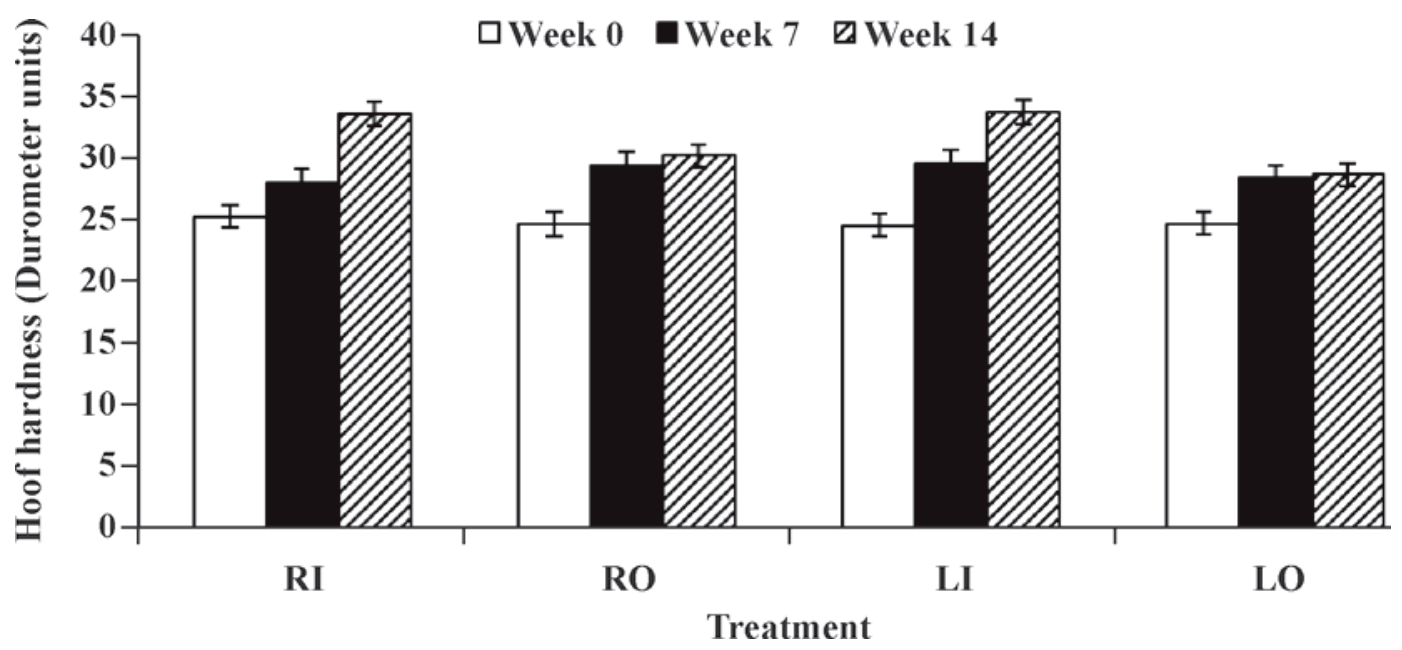

Figure 2. Effect of level and form of dietary $\mathrm{Zn}$ on hoof hardness of cows fed diets that contained either the recommended level of inorganic (RI) or organic $(\mathrm{RO}) \mathrm{Zn}$ or 0.66 of the recommended level per d of inorganic (LI) or organic (LO) Zn. Error bars = SEM. 
Table 4. Effect of level and form of dietary Zn on blood hematology

\begin{tabular}{|c|c|c|c|c|c|c|c|c|}
\hline Item $^{1}$ & \multicolumn{5}{|c|}{ Treatments } & \multicolumn{3}{|c|}{ Significance } \\
\hline Plasma Zn, $\mu \mathrm{mol} / \mathrm{L}$ & 13.4 & 13.3 & 13.6 & 14.1 & 0.59 & 0.623 & 0.374 & 0.785 \\
\hline Plasma Fe, $\mu \mathrm{mol} / \mathrm{L}$ & 30.9 & 30.7 & 33.0 & 29.4 & 1.86 & 0.762 & 0.176 & 0.208 \\
\hline Plasma Mo, $\mu \mathrm{mol} / \mathrm{L}$ & 0.26 & 0.27 & 0.25 & 0.25 & 0.01 & 0.076 & 0.970 & 0.767 \\
\hline Ceruloplasmin, mg/dL & 20.5 & 19.8 & 16.9 & 18.1 & 1.82 & 0.046 & 0.836 & 0.472 \\
\hline RBC, $10^{6} / \mathrm{mm}^{3}$ & 6.04 & 6.02 & 6.13 & 5.87 & 0.208 & 0.866 & 0.337 & 0.435 \\
\hline $\mathrm{HCT}, \%$ & 28.3 & 28.2 & 29.0 & 27.8 & 0.790 & 0.265 & 0.766 & 0.340 \\
\hline $\mathrm{MCV}, \mu \mathrm{m}^{3}$ & 47.0 & 47.4 & 47.5 & 47.8 & 1.369 & 0.645 & 0.713 & 0.914 \\
\hline $\mathrm{MCH}, \mathrm{pg}$ & 16.1 & 15.9 & 16.2 & 16.0 & 0.481 & 0.718 & 0.604 & 0.902 \\
\hline MCHC, g/dL & 33.9 & 33.8 & 33.8 & 33.8 & 0.145 & 0.529 & 0.524 & 0.458 \\
\hline PLT, $10^{3} / \mathrm{mm}^{3}$ & 553 & 491 & 569 & 557 & 39.03 & 0.150 & 0.190 & 0.382 \\
\hline
\end{tabular}

${ }^{1} \mathrm{WBC}=$ white blood cells; $\mathrm{RBC}=$ red blood cells; HGB = hemoglobin; HCT = hematocrit; PLT = platelets; MCV = mean corpuscular volume; $\mathrm{MCH}=$ mean corpuscular hemoglobin; and $\mathrm{MCHC}=$ mean corpuscular hemoglobin concentration.

${ }^{2}$ Diets contained: $\mathrm{RI}=$ recommended daily level of inorganic $\mathrm{Zn}$; RO = recommended level of organic $\mathrm{Zn}$; LI = low (0.66 of the recommended) level of inorganic $\mathrm{Zn}$; $\mathrm{LO}=$ low level of organic $\mathrm{Zn}$.

${ }^{3} \mathrm{~L}=$ main effect of level of $\mathrm{Zn} ; \mathrm{F}=$ main effect form of $\mathrm{Zn} ; \mathrm{L} \times \mathrm{F}=$ interaction between level and form of $\mathrm{Zn}$.

uted more than $800 \mathrm{mg} /$ cow per day) were not taken into consideration. Even though the levels of Zn were greater in the study reported by Nocek et al. (2006), the results from the current study support the observation that dietary Zn level has little effect on BW or BCS in lactating dairy cows. The form of Zn also does not appear to have an effect on BW (Whitaker et al., 1997) or BCS (Uchida et al., 2001). Similarly, Nocek et al. (2006) reported no significant effect when $\mathrm{Zn}$ was fed as either as inorganic (sulfate) or organically chelated (amino acid complex) on BW or BCS, an observation in agreement with the current study, in which Zn was supplemented as either an oxide or in organic form.

Cows receiving the level of $\mathrm{Zn}$ recommended by NRC (2001) in an organic form had the highest milk yield, an effect that was observed after $8 \mathrm{wk}$ of supplementation (Figure 1) and is supported by the findings of Kincaid and Socha (2004), who also reported an increase in milk yield between wk 5 and 10 postpartum in high-yielding dairy cows when supplemented with complexed minerals. In the current study, this increase was equivalent to $2.4 \mathrm{~kg} / \mathrm{d}$ over the 14 -wk period; however, the overall means for the RO treatment were not significantly different from that of the LI treatment. Miller et al. (1989) examined the effects of supplementing $\mathrm{Zn}$ at $0,1,000$, or $2,000 \mathrm{mg} / \mathrm{kg}$ on a DM basis in the form of $\mathrm{ZnSO}_{4}$ on lactating and gestating dairy cows and reported that at $1,000 \mathrm{mg} / \mathrm{kg}$ of DM there was no effect on milk production, whereas a supplemental level of $2,000 \mathrm{mg} / \mathrm{kg}$ of DM had an adverse effect on production, although this effect was not observed until after wk 26 of supplementation when daily milk production was decreasing.
Nocek et al. (2006) reported an increased milk production in animals receiving diets containing organically complexed minerals and a mixture of inorganic and organically complexed minerals. In contrast, Uchida et al. (2001) reported no increase in milk production. The diets in the studies by Nocek et al. (2006) and Uchida et al. (2001) were both supplemented with a mixture of complexed minerals and supplemented in excess of NRC (2001) requirements, and do not permit the improvement in performance to be identified to one specific mineral. Other studies have observed that feeding organic minerals such as zinc methionine (Spears, 1996; Kellogg et al., 2004) or zinc lysine (Kincaid and Cronrath, 1993) can increase milk production. In contrast, Campbell et al. (1999) reported no effect on milk yield by feeding minerals in an organic form.

Neathery et al. (1973) reported no differences in milk composition when supplementing varying levels of $\mathrm{Zn}$ in the diet, agreeing with the results from the current study. There was also no effect of Zn form on milk fat or protein, results agreeing with work carried out by Nocek et al. (2006). The concentration of $\mathrm{Zn}$ in milk is maintained over varying concentrations of dietary $\mathrm{Zn}$ (Krebs, 1998). It is thought that this is because the mammary gland's import and export process of $\mathrm{Zn}$ has a strict regulation to maintain an adequate supply of Zn to the neonate (Kelleher and Lönnerdal, 2005). This may explain the lack of an effect on milk Zn concentrations in the current study.

The level of Zn had a positive effect on udder health, with the recommended level of organic and inorganic $\mathrm{Zn}$ reducing SCC and milk amyloid A concentrations. 
The increase in SCC count for cows receiving the lower level of $\mathrm{Zn}$ supplementation could be attributed to a decrease in leukocyte function which would then result in an increase in the mammary gland's susceptibility to bacterial infection (Sordillo et al., 1997). Milk amyloid $\mathrm{A}$ is one of the major acute phase proteins in cattle and has the potential to be a useful disease marker as normal animals have low concentrations, followed by a rapid increase in concentration during the acute phase of inflammation (Eckersall et al., 2001). Those authors reported milk amyloid A levels for cows with moderate mastitis of $>1.2 \mu \mathrm{g} / \mathrm{mL}$. Cows receiving either the RI or RO treatments had mean milk amyloid A levels concentrations below this threshold, suggesting they had a lower mastitis challenge during the study. By contrast, animals receiving either LI or LO had milk amyloid A concentrations $>1.2 \mu \mathrm{g} / \mathrm{mL}$, suggesting a greater challenge. Kellogg et al. (2004) suggested that organic Zn reduces SCC in cattle, resulting in a healthier udder and thus improving milk yield. This could account for the increase in milk yield observed in animals receiving RO. The form of $\mathrm{Zn}$ in this study, however, did not have an effect on decreasing SCC. In contrast, Hansen (1992) and Kinal et al. (2005) reported a decrease in SCC from feeding organically chelated Zn, although this may be attributed to the high initial SCC, with averages $>400,000$ cells $/ \mathrm{mL}$ at the start of their studies, compared with an average of 130,000 cells/mL here. Other investigations of the effects of organic Zn on SCC which had low SCC of around 150,000 cells $/ \mathrm{mL}$ also reported no effect of form of dietary Zn on SCC; however, a reduction in mastitis rates was reported (Spain et al., 1993). It can be concluded that beneficial effects of inorganic or organic Zn fed at NRC (2001) on SCC are dependent on initial levels.

Supplementing cattle diets with Zn has been shown by Moore et al. (1988) to improve claw integrity by reducing the incidence of foot rot, heel cracks, interdigital dermatitis, and laminitis resulting in improved locomotion. The level or form of supplemental Zn did not have an effect on locomotion scores during the 14-wk study. Stern et al. (1998) stated that Zn deficiency can cause parakeratosis and hyperkeratosis in the epidermis of the hoof and, according to Tomlinson et al. (2004), if the nutrient is interrupted, formation of inferior horn of the cow's feet can result, causing claw disorders and subsequently lameness. Zinc has been identified as one of the key minerals in the processes of keratinization (Tomlinson et al., 2004) and greater concentrations of Zn are found in the harder keratin of the hoof wall compared with the softer keratin in the heel (Baggott et al., 1988). Also, the concentration of $\mathrm{Zn}$ in the hoof wall in lame animals has been reported to contain significantly less $\mathrm{Zn}$ compared with normal animals (Baggott et al., 1988). Level and form of supplemented Zn again resulted in no difference in hoof hardness, a finding in agreement with Griffiths et al. (2007). The duration of this study (14 wk) could have been responsible for the lack of effect on locomotion and hoof hardness, as hoof growth is accepted to be around $4.5 \mathrm{~mm}$ per month.

All cattle had adequate blood plasma Zn levels, suggesting that the treatment diets provided sufficient Zn to meet animal requirements during the period of this study (Kincaid, 1999). In contrast, Kinal et al. (2005) reported an increase in blood plasma Zn when animals were supplemented with organically chelated minerals compared with inorganic (sulfate) minerals. Cows receiving treatments RI or RO had a tendency for increased ceruloplasmin concentrations compared with cows receiving $\mathrm{LI}$ or $\mathrm{LO}$, a finding in agreement with Swerdel and Cousins (1984), who reported increased levels in rats fed $\mathrm{Zn}$. An increase in plasma $\mathrm{Cu}$ would have been expected due to the increase in ceruloplasmin activity; however, this was not observed. From the results of the superoxide dismutase (a $\mathrm{Cu}-\mathrm{Zn}$ containing enzyme), $\mathrm{Cu}$ plasma, and Mo plasma levels, it is suggested that feeding $\mathrm{Zn}$ at the recommended or lower level in either form does not affect $\mathrm{Cu}$ metabolism. There was no difference in blood hematology values across all 4 treatments, indicating that that the level and form of dietary $\mathrm{Zn}$ had no effect on erythrocytes and leucocytes.

\section{CONCLUSIONS}

Supplementing Zn in an organic form for 14 wk in early lactation had no significant effect on DM intake, milk composition, locomotion, hoof hardness, or blood hematology. This study does, however, demonstrate a significant benefit in milk yield from supplementing Zn at the recommended level of inclusion in an organically chelated form. Supplementing Zn in either form at the recommended level led to a decrease in SCC and milk amyloid A concentrations. The reduction in SCC counts and milk amyloid A at the recommended level occurred even when initial counts were low and merits further investigation.

\section{ACKNOWLEDGMENTS}

The authors are grateful to the Knowledge Transfer Partnerships, Alltech (UK) Ltd., and Department of the Environment, Food and Rural Affairs for funding the work. The authors acknowledge the technical support of D. Ferguson, G. Vince, R. Atkinson, A. Bentham, T. Mitchell and M. Larwood at Harper Adams University College. 


\section{REFERENCES}

Baggott, D. G., K. J. Bunch, and K. R. Gill. 1988. Variations in some inorganic components and physical properties of claw keratin associated with claw disease in the British Friesian cow. Br. Vet. J. 144:534-542.

Campbell, M. H., J. K. Miller, and F. N. Schrick. 1999. Effect of additional cobalt, copper, manganese, and zinc on reproduction and milk yield of lactating dairy cows receiving bovine somatotropin. J. Dairy Sci. 82:1019-1025.

Eckersall, P. D., F. J. Young, C. McComb, C. J. Hogarth, S. Safi, A. Weber, T. McDonald, A. M. Nolan, and J. L. Fitzpatrick. 2001. Acute phase proteins in serum and milk from dairy cows with clinical mastitis. Vet. Rec. 148:35-41.

Griffiths, L. M., S. H. Loeffler, M. T. Socha, D. J. Tomlinson, and A. B. Johnson. 2007. Effects of supplementing complexed zinc, manganese, copper and cobalt on lactation and reproductive performance of intensively grazed lactating dairy cattle on the South Island of New Zealand. Anim. Feed Sci. Technol. 137:69 83.

Hansen, R. 1992. Effects of Bioplex Zinc supplements on somatic cell counts in three high producing dairy herds. Pages 55-57 in Biotechnol. Feed Ind., Proc. Alltech's 8th Annu. Symp. Nicholasville, KY.

Henry, R. J., D. C. Cannon, and J. W. Winkelman. 1974. Clinical Chemistry: Principles and Techniques. Harper and Row, London, UK.

Jackson, M. A., R. J. Readman, J. A. Huntington, and L. A. Sinclair. 2004. The effects of processing at harvest and cutting height of urea-treated whole-crop wheat on performance and digestibility in dairy cows. Anim. Sci. 78:467-476.

Kelleher, S. L., and B. Lönnerdal. 2005. Molecular regulation of milk trace mineral homeostasis. Mol. Aspects Med. 26:328-339.

Kellogg, D. W., D. J. Tomlinson, M. T. Socha, and A. B. Johnson. 2004. Review: Effects of zinc methionine complex on milk production and somatic cell count of dairy cows: Twelve-trial summary. Prof. Anim. Sci. 20:295-301.

Kinal, S., A. Korniewiez, D. Jamroz, R. Zieminski, and M. Slupezynska. 2005. Dietary effects of zinc, copper and manganese chelates and sulphates on dairy cows. J. Food Agric. Environ. 3:168-172.

Kincaid, R. L. 2000. Assessment of trace mineral status of ruminants: A review. J. Anim. Sci. 77(E. Suppl.):1-10.

Kincaid, R. L., and D. J. Cronrath. 1993. Effects of added dietary fat and amino acids on performance of lactating cows. J. Dairy Sci. 76:1601-1606

Kincaid, R. L., and M. T. Socha. 2004. Inorganic versus complexed trace mineral supplements on performance of dairy cows. Prof. Anim. Sci. 20:66-73.

Krebs, N. F. 1998. Zinc supplementation during lactation. Am. J. Clin. Nutr. 68(Suppl.):509-512.

Lowman, B. G., N. A. Scott, and S. H. Somerville. 1976. Condition scoring of cattle. ESCA Bulletin no. 6. East of Scotland College of Agriculture, Ayrshire, Scotland.
Malcolm-Callis, K. J., G. C. Duff, S. A. Gunter, E. B. Kegley, and D. A. Vermeire. 2000. Effects of supplemental zinc concentration and source on performance, carcass characteristics, and serum values in finishing beef steers. J. Anim. Sci. 78:2801-2808.

Manson, R. J., and J. D. Leaver. 1988. The influence of concentrate amount on locomotion and clinical lameness in dairy cattle. Anim. Prod. 47:185-190.

Miller, W. J., H. E. Amos, R. P. Gentry, D. M. Blackmon, R. M. Durrance, C. T. Crowe, A. S. Fielding, and M. W. Neathery. 1989. Long-term feeding of high zinc sulfate diets to lactating and gestating dairy cows. J. Dairy Sci. 72:1499-1508.

Moore, C. L., P. M. Walker, M. A. Jones, and J. M. Webb. 1988. Zinc methionine supplementation for dairy cows. J. Dairy Sci. 71(Suppl. 1):152. (Abstr.)

National Research Council. 2001. Nutrient Requirements of Dairy Cattle. 7th rev. ed. National Academy of Sciences, Washington, DC

Neathery, M. W., W. J. Miller, D. M. Blackmon, and R. P. Gentry. 1973. Performance and milk zinc from low intake in Holstein cows. J. Dairy Sci. 56:212-217.

Nocek, J. E., M. T. Socha, and D. J. Tomlinson. 2006. The effect of trace mineral fortification level and source on performance of dairy cattle. J. Dairy Sci. 89:2679-2693.

Sordillo, L. M., K. Shafer-Weaver, and D. DeRosa. 1997. Bovine Immunology - Immunobiology of the Mammary Gland. J. Dairy Sci. $80: 1851-1865$.

Spain, J. N., B. J. Stevens, D. K. Hardin, and J. G. Thorne. 1993 Effects of Bioplex Zinc or zinc oxide on mastitis incidence in lactating dairy cows. Pages 53-60 in Biotechnol. Feed Ind., Proc. Alltech's 9th Annu. Symp., Nicholasville, KY.

Spears, J. W. 1996. Organic trace minerals in ruminant nutrition. Anim. Feed Sci. Technol. 58:151-163.

Stern, A., H. Geyer, I. Morel, and J. Kessler. 1998. Effects of organic zinc on horn quality in beef cattle. Pages 232-235 in 10th Int. Symp. Lameness Rumin., Lucerne, Switzerland.

Swerdel, M. R., and R. J. Cousins. 1984. Reduction of adjuvant induced arthritis and concomitant in ceruloplasmin and metallothionein synthesis in rats by zinc and 13-cis-retionic acid. Fed. Proc. 43:2344. (Abstr.)

Tomlinson, D. J., C. H. Mulling, and T. M. Fakler. 2004. Invited Review: Formation of keratins in the bovine claw: Roles of hormones, minerals and vitamins in functional claw integrity. J. Dairy Sci. 87:797-809

Uchida, K., P. Mandebvu, C. S. Ballard, C. J. Sniffen, and M. P. Carter. 2001. Effect of feeding a combination of zinc, manganese and copper amino acid complexes, and cobalt glucoheptonate on performance of early lactation high producing dairy cows. Anim. Feed Sci. Technol. 93:193-203.

Whitaker, D. A., H. F. Eayres, K. Aitchison, and J. M. Kelly. 1997. No effect of a dietary zinc proteinate on clinical mastitis, infection rate, recovery rate and somatic cell count in dairy cows. Vet. J. 153:197-204. 